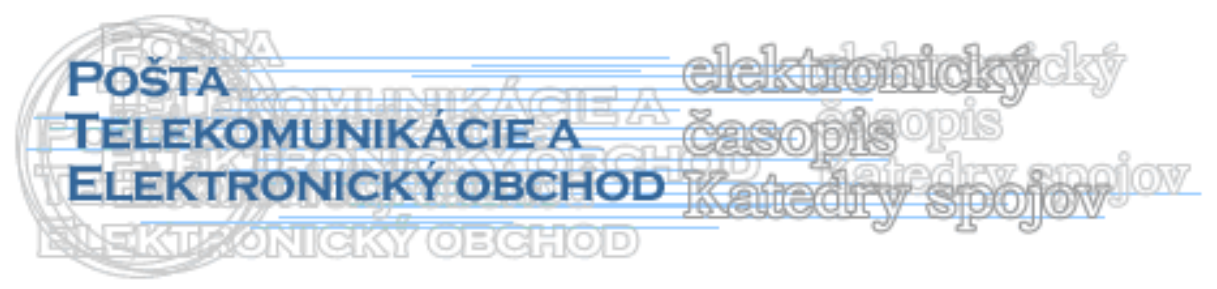

\title{
QUALITY MANAGEMENT APPROACH IN IT SERVICES
}

\author{
Zuzana Hnatová ${ }^{1}$, Peter Kolarovszki ${ }^{2}$
}

\section{Introduction}

In the past, many IT organisations were internally focused and concentrated on technical issues. These days, businesses have high expectations towards the quality of services and these expectations change with time. This means that for IT organisations to live up to these expectations, they need to concentrate on service quality and a more customer oriented approach. Cost issues are now high on the agenda as is the development of a more business like attitude to provision of service.

Tactical processes are centered on the relationships between the IT organisation and their customers.

There is a strong relationship with quality systems such as ISO 9000 and a total quality framework such as European Foundation for Quality Management (EFQM).

This article provides more information on quality management. Generic benefits include:

- improved quality service provision,

- cost justifiable service quality,

- services that meet business, customer and user demands,

- integrated centralised processes,

- everyone knows their role and knows their responsibilities in service provision,

- learning from previous experience,

- demonstrable performance indicators.

\section{Quality Management for IT Services}

Quality management for IT Services is a systematic way of ensuring that all the activities necessary to design, develop and implement IT services which satisfy the requirements of the organisation and of users take place as planned and that the activities are carried out cost effectively.

The way that an organisation plans to manage its operations so that it delivers quality services, is specified by its quality management system. The quality management system defines the organisational structure, responsibilities, policies, procedures, processes, standards and resources required to deliver quality IT services. However, a quality management system will only function as intended if management and staff are committed to achieving its objectives.

\footnotetext{
${ }^{1}$ Ing. Zuzana Hnatová, Žilinská univerzita v Žiline, Fakulta prevádzky a ekonomiky dopravy a spojov, Katedra spojov, Univerzitná 8215/1, 01026 Žilina, Slovenská republika, tel.: +421 415133145 , fax: +421 41565 5615, e-mail: Zuzana.Hnatova@fpedas.uniza.sk

${ }^{2}$ Ing. Peter Kolarovszki, Žilinská univerzita v Žiline, Fakulta prevádzky a ekonomiky dopravy a spojov, Katedra spojov, Univerzitná 8215/1, 01026 Žilina, Slovenská republika, tel.: +421 41513 3144, fax: +421 41565 5615, e-mail: Peter.Kolarovszki@fpedas.uniza.sk
} 


\subsection{Ongoing quality improvement: The Deming Cycle}

"We have learned to live in a world of mistakes and defective products as if they were necessary to life. It is time to adopt a new philosophy..."

(W. Edwards Deming, 1900-93) [3]

W. Edwards Deming is best known for his management philosophy establishing quality, productivity, and competitive position. As part of this philosophy he formulated 14 points of attention for managers. Some of these points are more appropriate to Service Management than others, for example:

Excerpts from Deming's fourteen points relevant to Service Management:

- break down barriers between departments (improves communications and management),

- $\quad$ management must learn their responsibilities, and take on leadership (process improvement requires commitment from the top; good leaders motivate people to improve themselves and therefore the image of the organisation),

- improve constantly (a central theme for Service Managers is continuous improvement; this is also a theme for quality management. A process-led approach is key to achieving this target),

- institute a programme of education and self-improvement (learning and improving skills has been the focus of Service Management for many years),

- $\quad$ training on the job (linked to continuous improvement),

- transformation is everyone's job (the emphasis being on teamwork and understanding).

For quality improvement Deming proposed the Deming Cycle (or Circle). The four key stages are plan, do, check and act after which a phase of consolidation prevents the 'Circle' from 'rolling down the hill' as illustrated in Figure 1. The consolidation phase enables the organisation to take stock of what has been taking place and to ensure that improvements are embedded. Often, a series of improvements have been made to processes that require documentation (both to allow processes to be repeatable and to facilitate recognition of the achievement of some form of quality standard).

The cycle is underpinned by a process-led approach to management, where defined processes are in place, the activities are measured for compliance with expected values, and outputs are audited to validate and improve the process. 


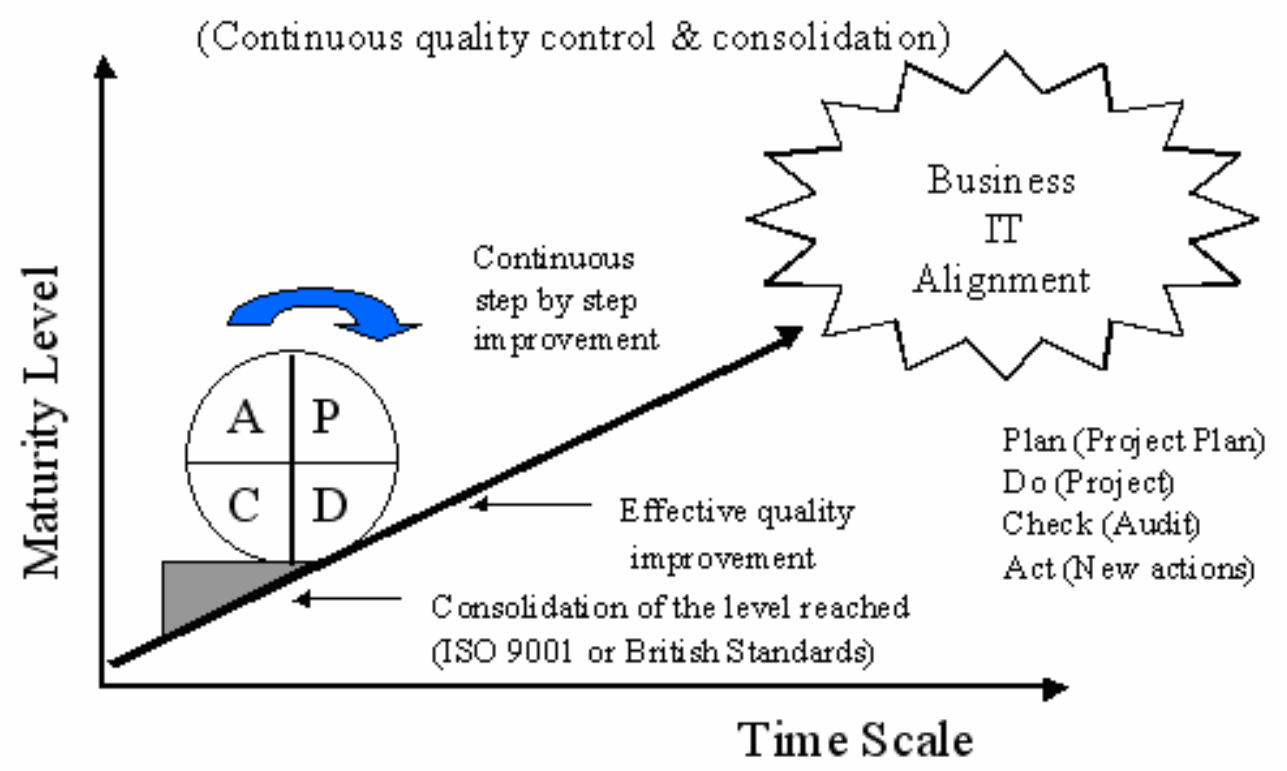

Figure 1 - The Deming Cycle [3]

\subsection{Quality standards}

International Standards Organisation ISO 9000

An important set of International Standards for Quality Assurance is the ISO 9000 range, a set of five universal standards for a Quality Assurance system that is accepted around the world. More than 90 countries have adopted ISO 9000 as the cornerstone of their national standards. When you purchase a product or service from a company that is registered to the appropriate ISO 9000 standard, you have important assurances that the quality of what you will receive will be as you expect.

The most comprehensive of the standards is ISO 9001. It applies to industries involved in the design, development, manufacturing, installation and servicing of products or services. The standards apply uniformly to companies in any industry and of any size.

\section{Total Quality Systems: EFQM}

"...the battle for Quality is one of the prerequisites for the success of your companies and for our collective success". ${ }^{3}$

(Jacques Delors) [3]

\section{The EFQM excellence model}

The European Foundation for Quality Management (EFQM) was founded in 1988 by the Presidents of 14 major European companies, with the endorsement of the European Commission. The present membership is in excess of 600 very well respected organisations, ranging from major multinationals and important national companies to research institutes in prominent European universities.

EFQM provides an excellent model for those wishing to achieve business excellence in a programme of continuous improvement.

\footnotetext{
${ }^{3}$ Jacques Delors, President of the European Commission, at the signing of the letter of intent in Brussels to establish EFQM on 15 September 1988.
} 


\section{EFQM mission statement}

\section{The mission statement is:}

To stimulate and assist organisations throughout Europe to participate in improvement activities leading ultimately to excellence in customer satisfaction, employee satisfaction, impact on society and business results; and to support the managers of European organisations in accelerating the process of making Total Quality Management a decisive factor for achieving global competitive advantage. [1]

\section{Depiction of the EFQM excellence model}

The EFQM Excellence Model consists of 9 criteria and 32 sub-criteria; it is illustrated in Figure 2:

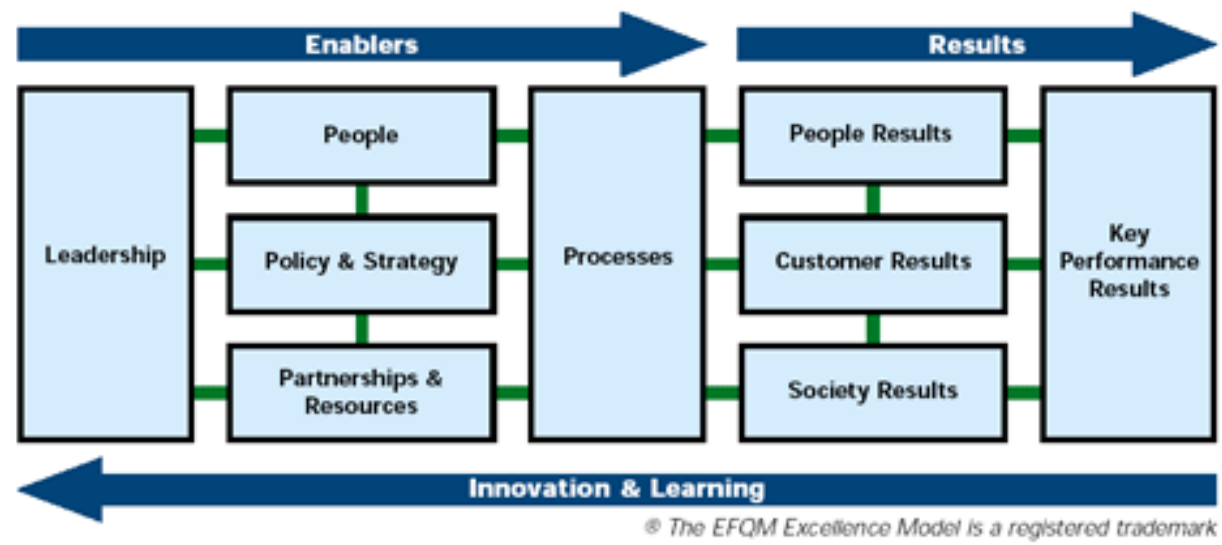

Figure 2 - The EFQM excellence model [5]

In the model there is explicit focus on the value to users of the 'Plan, Do, Check, Act' cycle to business operations, and the need to relate everything that is done, and the measurements taken, to the goals of business policy and strategy.

\section{Self-assessment and maturity; the EFQM maturity scale}

One of the tools provided by EFQM is the self-assessment questionnaire. The selfassessment process allows the organisation to discern clearly its strengths and also any areas where improvements can be made. The questionnaire process and culminates in planned improvement actions, which are then monitored for progress.

In this assessment progress can be checked against a five-point maturity scale:

1. product orientation,

2. process orientation,

3. system orientation,

4. chain orientation,

5. total quality.

\section{Quality awards}

To demonstrate a successful adaptation of the EFQM model, some companies aim for the European Quality Award, a process that allows Europe to recognize its most successful organisations and promote them as role models of excellence for others to copy. [3]

The US equivalent to this award is the Malcolm Baldridge Quality Award for Quality management. The Malcolm Baldrige National Quality Improvement Act of 1987, established 
an annual US National Quality Award. The purpose of the Award was (and still is) to promote awareness of quality excellence, to recognise quality achievements of US companies, and to publicise successful quality strategies.

For the Malcolm Baldridge Award, there are three categories:

- manufacturing companies or subunits,

- service companies or subunits,

- small businesses.

The criteria against which firms are judged are:

1. leadership,

2. strategic planning,

3. customer and market focus,

4. information and analysis,

5. human resource development and management,

6. process management,

7. business results.

For the European Quality Award, there are four possible categories:

- companies,

- operational units of companies,

- public-sector organisations,

- small and medium enterprises.

The criteria against which candidate organisations are measured are:

1. leadership,

2. people,

3. policy and strategy,

4. partnerships and resources,

5. processes,

6. people results,

7. customer results,

8. society results,

9. key performance results. [4]

\section{Conclusion}

Many companies require their suppliers to become registered to ISO 9001 and because of this, registered companies find that their market opportunities have increased. In addition, a company's compliance with ISO 9001 ensures that it has a sound Quality Assurance system.

Registered companies have had dramatic reductions in customer complaints, significant reductions in operating costs and increased demand for their products and services.

ISO 9000 registration is rapidly becoming and should for any company that does business in Europe. Many industrial companies require registration by their own suppliers. There is a growing trend toward universal acceptance of ISO 9000 as an international standard.

Of course this applies to other standards, for example the British Standards, and in fact most European and many other standards world-wide have been consolidated in the new ISO 9000-2000 standards. 


\section{References}

[1] MARQUIS, H. How to roll the Deming wheel. ITSM solutions DITY newsletter reprint [online] May, 2006, Volume 2.20. [citované 21.11.2007]. Dostupné Z $<\mathrm{http}$ //Www.itsmsolutions.com/newsletters/DITYvol2iss20.pdf $>$

[2] Office of Government Commerce. Service delivery. London: The Stationery Office, 2000, 306 p. ISBN 0113300174

[3] Office of Government Commerce. Service support. London: The Stationery Office, 2000, 200 p. ISBN 0113300158

[4] VAN BON, J. Foundations of IT Service Management Based on ITIL. Van Haren publishing, 2005, 231 p. ISBN 9077212582

[5] MATTHEW, M. What is...The EFQM Excellence Model? [online] August, 2007, [citované 10.3.2008]. Dostupné $\mathrm{z}<\mathrm{http}: / / \mathrm{www}$.onesixsigma.com/article/what-is-theefqm-efficiency-model>

\section{Grantová podpora}

Článok vznikol na podporu projektov:

VEGA 1/0709/08 - Poskytovanie verejnej telefónnej služby a spôsoby jej hodnotenia v procese globalizácie.

MVTS Nem/SR/ŽU2/07 - Zákaznícka spokojnost' v bankovom sektore. 